\title{
An effective and economic method to produce re-ripe honey with honeybee colonies
}

\author{
Nana GUO ${ }^{1}$, Qingyu WANG ${ }^{1}$, Lei SHEN ${ }^{2}, \mathrm{Lu} \mathrm{WANG}^{3}$, Yazhou ZHAO ${ }^{1 \star}$ (D)
}

\begin{abstract}
Beekeepers who manage migratory beekeeping in China preferred to produce non-ripe honey rather than natural ripe honey in short flowering seasons, to obtain higher honey yield and profits. To explore an alternative method for production of ripe honey, we fed Apis cerana cerana colonies with non-ripe honey produced from Apis mellifera ligustica colonies to produce re-ripe honey. The production rate of re-ripe honey was $29.06 \%$, which led to a high market profit considering price factors. The contents of glucose and fructose in re-ripe honey didn't change significantly, and small amounts of sucrose and maltose were detected. The amylase activity $\left(39.06 \mathrm{~mL} /\left(\mathrm{g}^{\star} \mathrm{h}\right)\right.$ in re-ripe honey significantly increased, compared with that $\left(34.86 \mathrm{~mL} /\left(\mathrm{g}^{\star} \mathrm{h}\right)\right)$ in non-ripe honey. The types and relative content of volatile organic components, namely, alcohols and esters, in re-ripe honey were lower than those in non-ripe honey, indicating the milder and non-irritating aroma of the former. Overall, the method raised by us is a practical approach to produce honey with high quality and economic values and could be easily accepted by the market.
\end{abstract}

Keywords: re-ripe honey; honeybee colony; non-ripe honey; amylase activity; sugar contents; volatile organic components.

Practical Application: Development of a novel way to produce ripe honey with honeybee colonies, which may help beekeepers make more economic profit.

\section{Introduction}

Ripe honey is a kind of natural sweet food with strong aroma and, is produced by honeybee colonies until most cells in the honeycomb are sealed (Naef et al., 2004). As suggested by previous reports, ripe honey is viscous and has water content lower than $22 \%$, which is not favorable for the growth of microorganisms; as such, the shelf life of ripe honey is prolonged (Aparna \& Rajalakshmi, 1999). Compared with ripe honey, non-ripe honey has higher water content and can easily ferment, crystallize, or even deteriorate under natural condition; in such conditions, non-ripe honey exhibits reduced sensory quality and safety for consumption (Iurlina \& Fritz, 2005). For example, high water content is favorable for the growth and reproduction of yeasts. It might also lead to the conversion of sugars into alcohol and $\mathrm{CO}_{2}$ in the process known as honey fermentation (Aldridge et al., 2016). However, unreasonable quality-price systems in apicultural practices have forced beekeepers to produce non-ripe honey during short flowering seasons to make high profit (Ismaiel et al., 2014). For example, in China honey enterprises needs to concentrate the commercially available non-ripe honey to meet legal food criteria. Traditional procedures for concentrating non-ripe honey include pre-warming, honey-melting, filtration, vacuum concentration, and cooling, which may induce changes in some components or nutrients, especially volatile organic components (VOCs) (Baroni et al., 2006; Xu et al., 2012). For instance, pre-warming exceeding $60^{\circ} \mathrm{C}$ in honey may induce Maillard reaction, which can destroy some monoses during heating process (Turkmen et al., 2006). Therefore, it is necessary to integrated the production of natural ripe honey to preserve the innate characters of this product and maintain the economic benefits for beekeepers.
Honey is rich in nutrients, including carbohydrates, many types of vitamins, trace elements, and bioactive enzymes. As the major components, carbohydrates account for 70\%-85\% of honey and mainly include glucose and fructose (Alvarez-Suarez et al., 2014). The type and content of carbohydrates are related to their nectar plants, local environment, harvesting seasons, and honey production process (Castro-Vázquez et al., 2014). For example, oligosaccharides, such as sucrose, are the main carbohydrates in nectar but are always detected in small quantity in honey. These oligosaccharides in nectar could be converted into monoses, which are hydrolyzed by enzymes secreted from honeybees or flowers (Ouchemoukh et al., 2010). Despite the small quantity of oligosaccharides in the honey, they can stimulate the growth and reproduction of Bifidobacteria and Lactobacillus and thus enhance human digestion (Ou \& Sun, 2014). At present, carbohydrates are always used to discriminate nectar sources, production areas, and authenticity of honey (Kaškoniene \& Venskutonis, 2010; Karousou et al., 2005; Baltrušaitytė et al., 2007). However, few studies have focused on examining changes in carbohydrates during honey production from non-ripe honey to ripe honey. Enzymes in honey play important roles in the conversion of nectar or honeydew into honey and are always used as sensitive index for evaluating honey quality (Kumar et al., 2010). Amylase secreted by honeybee can catalyze amylon hydrolysis, which is easily affected by storage time and high temperature. Therefore, a high amylase activity can be detected when honey is non-ripe or undergoes long storage. Based on these features, amylase is generally used as indicator of the ripeness degree and storage 
duration of honey (Ajlouni \& Sujirapinyokul, 2010). Similar to other food, honey aroma is a basic characteristic that affects consumers' acceptance. In general, aroma is mainly dependent on VOCs, which are also affected by nectar sources, honey production processes, and storage conditions (Manyi-Loh et al., 2011). Accurate description of the profiles of VOCs can help to evaluate the sensory quality of honey or even influence the market price of the product (Ferreira et al., 2009). The huge market demand for locust honey with a pleasing aroma leads to the high price of this commodity. Meanwhile, rape honey typically contains relatively high water content and is easily fermented and crystallized, leading to reduced sensory quality and price.

To obtain high honey yield and profit, some beekeepers prefer to produce non-ripe honey with Western honeybee (Apis mellifera) colonies. In recent years, many beekeeping organizations and consumers have claimed that effective methods for producing ripe honey should be applied to improve the quality and popularity of honey (Gao \& Zhao, 2016). In this study, we attempted to produce re-ripe honey from non-ripe honey by using Apis cerana cerana colonies, which consume lower amount of feed compared with Western honeybee colonies. The feasibility of producing re-ripe honey with honeybee colonies was estimated by comparing changes in production rate, water content, sugars content, amylase activity and VOCs between non-ripe honey and re-ripe honey.

\section{Materials and methods}

\subsection{Study site, experimental colonies, and climate conditions}

Three A. c. cerana colonies inhabiting the Guling Mountain in Fuzhou, China were selected to produce re-ripe honey. Before the experiment, the population sizes of all the colonies were adjusted to be basically uniform, and checked to be healthy. Honey stored in the colonies was extracted, and the queens were renewed in October 2016. The experiments were carried out from April 20, 2017 to April 30, 2017 when the local climate was cloudy and slightly rainy. The temperature was about $25^{\circ} \mathrm{C}$, and the relative humidity was about $70 \%$. The period was rainy season locally with no flowering plants around.

\subsection{Production of re-ripe honey}

Non-ripe honey sample was harvested from A. m. ligustica colonies located in Yicheng, China during the rape flowering season. Until the production of re-ripe honey began, the harvested non-ripe honey was crystallized. The sample was pre-warmed, stirred at $40{ }^{\circ} \mathrm{C}$ to completely melt it, and mixed with water at a ratio of 1:2. The mixture was used to feed colonies at a dosage of $2.1 \mathrm{~kg} /$ day/colony for 6 days. From day 7 to 10 , the colonies were not fed anymore. After 10 days, the colonies were checked daily to judge whether the covering rates of honeycombs reach more than $90 \%$. If yes, then honey was harvested and filtrated with 200-mesh gauze as re-ripe honey. Three sets of non-ripe honey samples $(500 \mathrm{~g} / \mathrm{sample})$ were randomly selected and labeled as A1, A2 and A3. Three sets of re-ripe honey samples $(500 \mathrm{~g} / \mathrm{sample})$ were also randomly selected and labeled as B1, B2 and B3.

\subsection{Measurement of water content}

The refractive index of honey samples was measured with Abbe refractometer (accuracy is 0.0001 units, WAY-2S, China). All measurements were performed at $20^{\circ} \mathrm{C}$, after waiting for $6 \mathrm{~min}$ for equilibrium, and obtaining the corresponding percentage of water content, which was determined based on the refractive index of honey in reference to the standard conversion table (Chataway, 1932).

\subsection{Measurement of sugar contents}

\section{Preparation of working standard solutions}

A series of $0.8,1.2,1.6,2.0$, and $2.4 \mathrm{~g}$ of precisely weighed glucose $( \pm 0.0001 \mathrm{~g})$ was dissolved in $60 \mathrm{~mL}$ of water. The solutions were individually transferred into $100 \mathrm{~mL}$ volumetric flask and added with acetonitrile (chromatography grade) to the marked scale. These solutions were the working standard solutions with concentrations of $8,12,16,20$, and $24 \mathrm{mg} / \mathrm{mL}$. The working standard solutions of fructose $(10,15,20,25$, and $30 \mathrm{mg} / \mathrm{mL})$, sucrose $(0.5,1.0,2.0,4.0$, and $6.0 \mathrm{mg} / \mathrm{mL})$ and maltose $(0.5,1.0,2.0,4.0$, and $6.0 \mathrm{mg} / \mathrm{mL})$ were also prepared using the same method.

\section{Preparation of sample solutions}

Crystallized honey was sealed and gently shaken at $60^{\circ} \mathrm{C}$ to completely melt and mix. After cooling to room temperature, $5 \mathrm{~g}( \pm 0.0001 \mathrm{~g})$ of honey sample was dissolved in $30 \mathrm{~mL}$ of water. The solution was transferred into $100 \mathrm{~mL}$ volumetric flaskand added with water to the marked scale. Parallel groups were prepared using the same method. The sample solutions were filtered by passing through $0.45 \mu \mathrm{m}$ filter membrane and saved for chromatography analysis.

\section{Liquid chromatography parameters}

A high performance liquid chromatography (HPLC) instrument equipped with differential refraction detector was used with carbohydrate column $(10 \mathrm{~m}, 200 \mathrm{~mm} \times 3.9 \mathrm{~mm})$. The mobile phase was acetonitrile + water $(77: 23)$ with flow rate set as $1.0 \mathrm{~mL} / \mathrm{min}$ and column temperature as $25^{\circ} \mathrm{C}$. The detector pool temperature was $35^{\circ} \mathrm{C}$, and the sample injection volume was $15 \mathrm{~L}$.

\section{Quantification of sugars in honey}

The prepared working standard solutions of fructose, glucose, sucrose and maltose were subjected to HPLC analysis to draw the working standard curves. The solutions of honey samples were also subjected to HPLC analysis. Sugar content in honey was calculated based on the working standard curves and expressed as percentage.

\subsection{Measurement of amylase activity}

Crystallized honey was sealed and gently shaken at $60^{\circ} \mathrm{C}$ to completely melt and mix. After cooling to room temperature, $5 \mathrm{~g}$ of honey and $5 \mathrm{~mL}$ of acetate buffer ( $\mathrm{pH} 5.3$ ) were added to $15 \mathrm{~mL}$ of water. The solution was then transferred into $50 \mathrm{~mL}$ 
volumetric flask added with $3 \mathrm{~mL}$ of $\mathrm{NaCl}$ solution $(0.5 \mathrm{~mol} / \mathrm{L})$, and diluted with water to the marked scale. The honey solution and $1 \%$ starch solution were separately pre-warmed in a water bath at $40{ }^{\circ} \mathrm{C}$ for $15 \mathrm{~min}$. The honey solution was then added with $5 \mathrm{~mL}$ of the starch solution to prepare starch-honey mixture. The absorbance of the mixture at $660 \mathrm{~nm}$ was recorded, and amylase activity was calculated according to the method provided by International Honey Commission (Al et al., 2009).

\section{Measurement of Volatile Organic Components (VOCs)}

\section{VOC extraction}

VOCs were extracted from honey through headspace solid-phase micro-extraction (HS-SPME) method. Before extraction, an SPME extractor was inserted into the chromatograph injection port and conditioned at $270{ }^{\circ} \mathrm{C}$ for $60 \mathrm{~min}$. Precisely weighed $8 \mathrm{~g}$ of honey was transferred into a bottle with $100 \mathrm{~mL}$ headspace and added with $10 \mathrm{~mL}$ of saturated $\mathrm{NaCl}$. The mixed solution in the headspace bottle was stirred and mixed with a magnetic stirrer at $50^{\circ} \mathrm{C}$ for $30 \mathrm{~min}$. The conditioned SPME extractor was inserted into the headspace bottle. The elicited fiber was kept above the mixed solution to absorb VOCs at $50^{\circ} \mathrm{C}$ for $40 \mathrm{~min}$. After the extraction was completed, the SPME extractor was inserted into the sample injection port of the gas chromatography instrument and the fiber was pulled out.

\section{Gas Chromatography (GC) parameters}

The temperature of the capillary column (DB-WAX, $30 \mathrm{~m} \times 0.25 \mathrm{~mm}, 0.25 \mu \mathrm{m}$ ) was initially kept at $40^{\circ} \mathrm{C}$ for $3 \mathrm{~min}$ and increased to $200{ }^{\circ} \mathrm{C}$ at $5{ }^{\circ} \mathrm{C} \mathrm{min}^{-1}$. The temperature was increased again to $240{ }^{\circ} \mathrm{C}$ at $5{ }^{\circ} \mathrm{C} \mathrm{min}-1$ and kept it for $5 \mathrm{~min}$. Ultrapure helium (purity $>99.999 \%$ ) was used as carrier gas, and the constant current velocity was $1.2 \mathrm{~mL} / \mathrm{min}$. The injector was operated in spitless mode at $250{ }^{\circ} \mathrm{C}$ and $14.82 \mathrm{psi}$.

\section{Mass Spectrometry (MS) parameters}

The temperature of electron impact (EI) ion source was set at $230^{\circ} \mathrm{C}$. EI mass spectrometry (EIMS) spectra were recorded at ionization energy of $70 \mathrm{eV}$. The temperatures of transmission line and quadrupole were set at $280^{\circ} \mathrm{C}$ and $150^{\circ} \mathrm{C}$, respectively. The solvent delay was set as $3 \mathrm{~min}$, and the scanning mass range was $55-500 \mathrm{~m} / \mathrm{z}$.

Qualitative and semi-quantitative identification of VOCs

The target VOCs were retrieved in the MS NIST 14 database for qualitative analysis. The peak area of the target VOC was compared with the total area of the peaks in ionic chromatogram to conduct semi-quantitative analysis.

\subsection{Data analysis}

Data processing was performed using SPSS 18.0 (SPSS, Inc, Chicago, IL, USA). Means and standard deviations (SDs) were calculated from triplicate measurements of each type of honey. One-way ANOVA was conducted, and differences in sugar contents or amylase activity among different types of honey were assessed using paired $t$-test.

\section{Results}

\subsection{Production rate of re-ripe honey}

For the three honeybee colonies, $26.15 \mathrm{Kg}$ of non-ripe honey was consumed in the experimental period of 11 days, and $10.71 \mathrm{~kg}$ of re-ripe honey was harvested during the experimental period. The production rate was $29.06 \%$ (Figure 1). During the experimental period, the amounts of non-ripe honey consumed by the three colonies were $8.26,9.03$ and $8.86 \mathrm{Kg}$, respectively, and the amounts of re-ripe honey produced by the three colonies were $3.33,3.71$, and $3.67 \mathrm{Kg}$, respectively. These results indicated minimal differences in non-ripe honey consumption and re-ripe honey production among colonies with uniform population sizes.

\subsection{Detection of sugars, water, and amylase activities from non-ripe and re-ripe honey}

As shown in Figure 2, the water content in re-ripe honey was $20.84 \% \pm 0.32 \%$, which significantly decreased compared with that of non-ripe honey $(24.49 \% \pm 0.15 \%, P<0.001)$. No significant difference in glucose and fructose contents were found between re-ripe honey and non-ripe honey, indicating that re-ripe honey production with colonies did not change the contents of main sugars. Small amounts of maltose and sucrose were detected in re-ripe honey but not in non-ripe

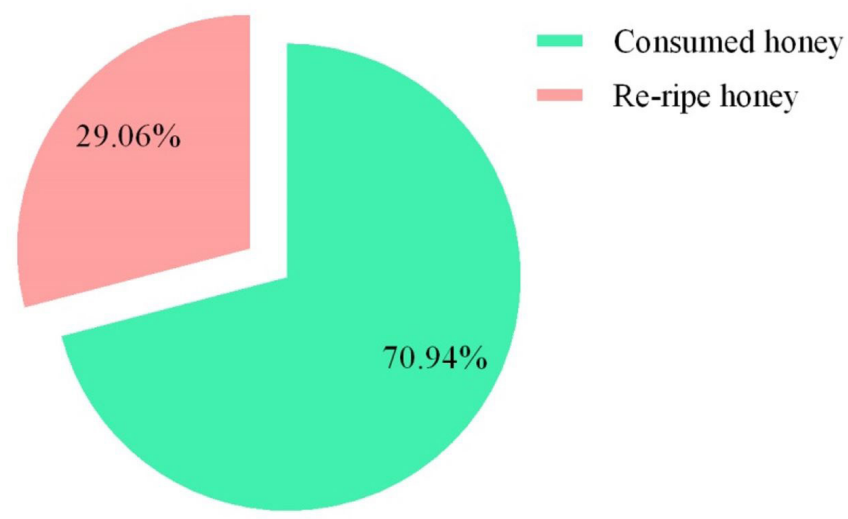

Figure 1. Production rate of re-ripe honey.

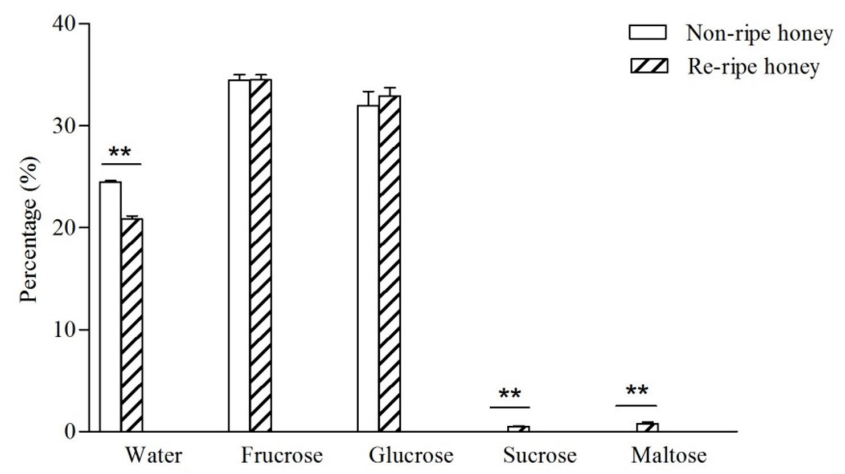

Figure 2. Contents of water and sugars in different types of honey [** indicates significant difference $(P<0.001)]$. 
honey. After re-ripe production, the amylase activity of re-ripe honey reached $39.06 \mathrm{~mL} /\left(\mathrm{g}^{\star} \mathrm{h}\right)$, which significantly increased compared with that of non-ripe honey (Figure 3 ).

\subsection{Total ionic chromatograms of VOCs}

For the two types of honey, the acquisition time of GC-MS was $45 \mathrm{~min}$, and the retention times of the VOC peaks were within 20-40 min (Figure 4). The VOC profiles of the two types of honey differed in the outline of ionic chromatograms, suggesting the different flavor profiles of non-ripe honey and re-ripe honey. These differences were mainly reflected by the retention time and the peak value of VOCs. Compared with those in re-ripe honey samples, the peak areas of VOCs in non-ripe honey samples were significantly larger; in particular, VOCs were detected within the retention time of 27-43 min.

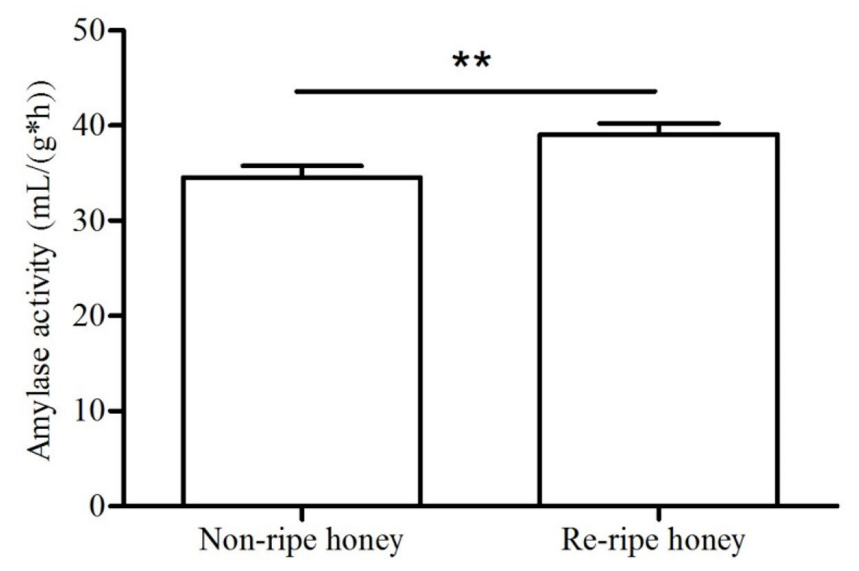

Figure 3. Amylase activities in different types of honey [** indicates significant difference $(P<0.001)]$.

\subsection{Qualitative and semi-quantitative analysis of VOCs}

Non-ripe honey was found to contain $75.33 \pm 4.51$ types of VOCs, which were higher than those in re-ripe honey $(61.00 \pm 3.46)$ based on GC-MS analysis. After classification analysis of these VOCs in honey, we found that most of the VOCs in both types of honey were esters, and fewest were ketones (Figure 5). Among all VOCs, the types of alcohols and esters in non-ripe honey were significantly higher than those in re-ripe honey. Meanwhile, the amount of acids, aldehydes and ketones were not significantly different between non-ripe honey and re-ripe honey. The relative contents of different types of VOCs were calculated according to the peak areas in their ionic chromatograms (Figure 6). The shapes in the radar charts considerably differed among different types of honey but were similar in the same type of honey. Although the relative contents of VOCs in the two types of honey were of the same magnitude (i.e. $10^{8}$ ), the relative contents of VOCs in non-ripe honey were significantly higher than those in re-ripe honey. Furthermore, non-ripe honey contained relatively higher contents of esters and alcohols.

\section{Discussion}

Naturally ripe honey contains about $22 \%$ of water and the disaccharides in nectar have been fully converted into monosaccharides in ripe honey. These monosaccharides mainly consist of glucose and fructose, accounting for $70 \%$ of sugars in ripe honey (Semkiw et al., 2010). Ripe honey undergoes a post-ripe process, namely, covering period, which removes the inherent acidic taste of nectar. Compared with non-ripe honey, ripe honey is more fragrant, throat smoothing, and viscous (Bogdanov et al., 2008). However, migratory beekeeping production approach is prevalent in China and worldwide, which has impelled beekeepers to immediately sell their produced honey to reduce the weight

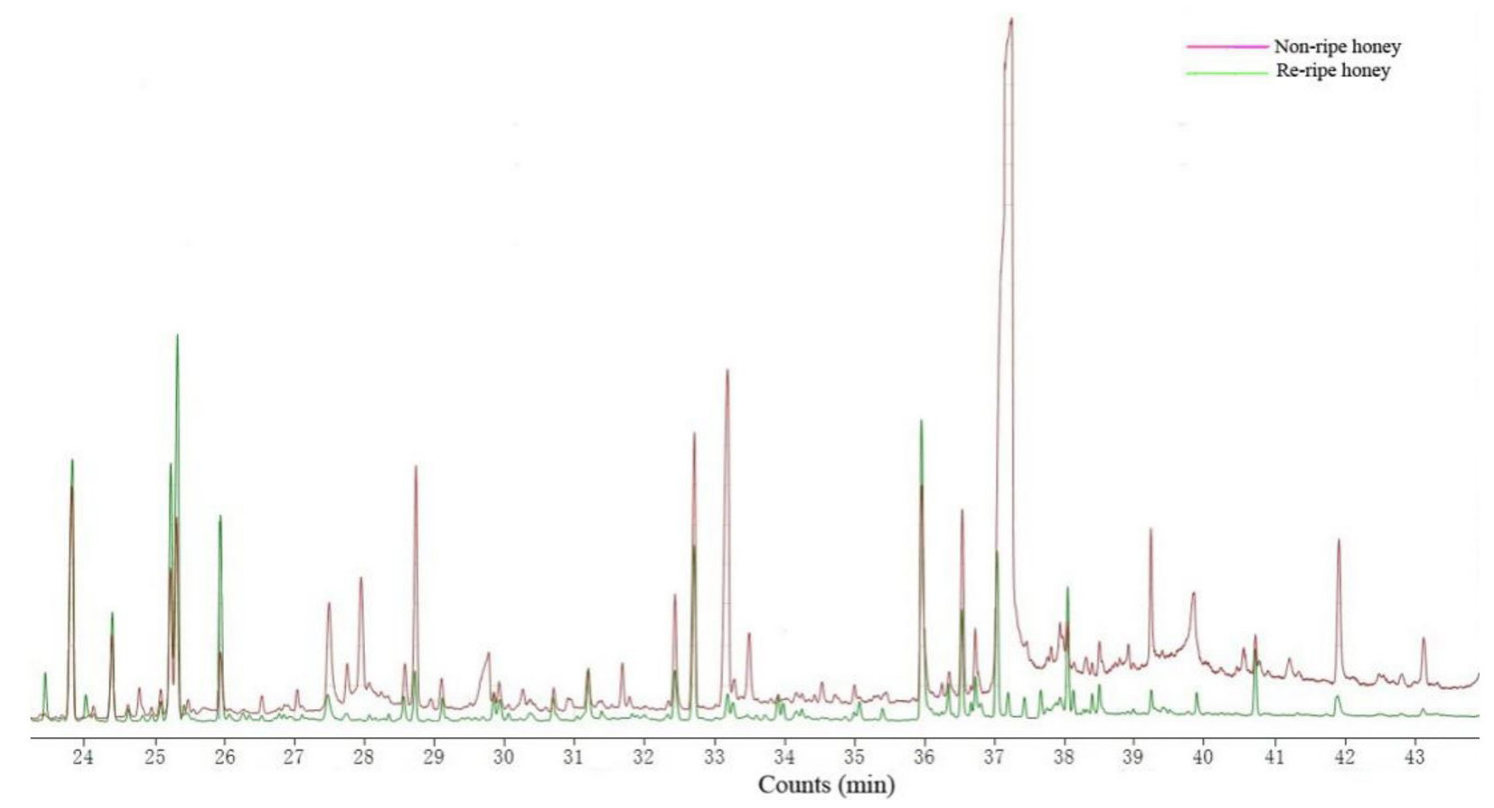

Figure 4. Total ionic chromatograms of VOCs in different types of honey. 
for colonies transportation. Therefore, large amounts of non-ripe honey are produced in short flowering seasons. To produce a high amount of ripe honey while maintaining or increasing the beekeepers' profit, we attempted using colonies to produce re-ripe honey with non-ripe honey. In this study, A. c. cerana colonies were fed with non-ripe honey produced by $A$. m. ligustica colonies to produce re-ripe honey, and the production rate was $29.06 \%$, which was obtained under strict and economic experimental conditions. For example, A. m. ligustica colonies were used to produce non-ripe honey as their higher honey yield (Cao et al.,

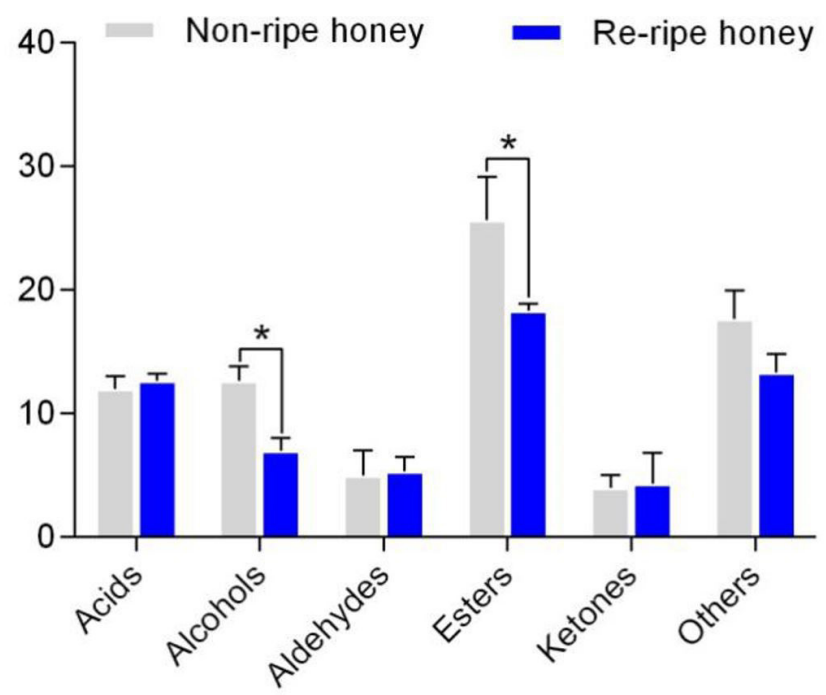

Figure 5. Classification of VOCs in different types of honey [ ${ }^{*}$ indicates significant difference $(P<0.05)]$.
2016), whereas A.c. cerana colonies were used to produce re-ripe honey as their lower honey consumption (Abusabbah et al., 2016). In the honey market in China, the current price of rape honey is $1.03 \$ / \mathrm{kg}$, or $3.56 \$ / \mathrm{kg}$ when divided by $29.06 \%$ (productive rate). If the price of re-ripe honey is higher than $3.56 \$ / \mathrm{kg}$, then the beekeepers can make a profit. However, high-grade ripe honey produced by A. c. cerana colonies is usually sold at about $14.77 \$ / \mathrm{kg}$, indicating the economic feasibility of producing re-ripe honey (Gao \& Zhao, 2016).

Compared with non-ripe honey, re-ripe honey possessed a significantly lower water content of $22 \%$, which basically satisfies the requirement of ripe honey accepted by consumers. The contents of glucose and fructose did not change after re-ripe honey production with colonies. However, sucrose and maltose were detected in re-ripe honey, and their contents were lower than $5 \%$, which still satisfies the international criteria of honey (Thrasyvoulou et al., 2018). Sucrose and maltose detected in re-ripe honey may be derived from castor sugar used to feed colonies in the early cold days before the experiment. Although frames within colonies were cleaned before the experiments, the residues of castor sugar were difficult to completely remove. The amylase activity was significantly improved after production of re-ripe honey because it underwent longer storage time in colonies than non-ripe honey. Worker bees need to repeatedly swallow and spit honey to make it ripe, and in the process much amylase is secreted into honey (Kumar et al., 2010). The improved amylase activity in re-ripe honey still satisfies the international criteria of honey (Thrasyvoulou et al., 2018), thereby confirming the feasibility of re-ripe honey production with colonies. The types and relative contents of VOCs, especially for esters and alcohols, differed between non-ripe honey and re-ripe honey. For example, esters in VOCs mainly contribute to
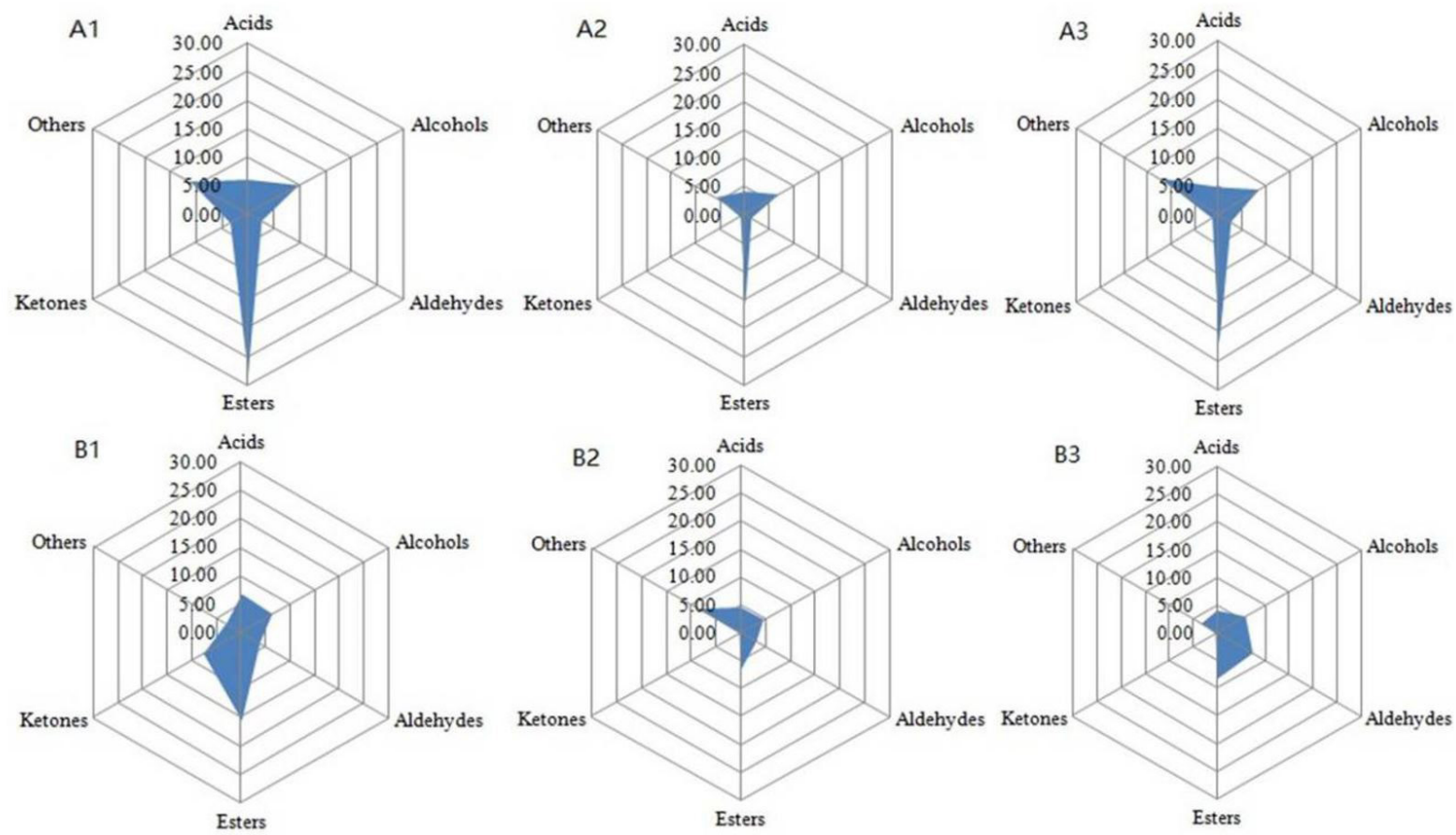

Figure 6. Relative contents of VOCs in different types of honey $\left(\times 10^{8}\right)(\mathrm{A} 1, \mathrm{~A} 2$, and A3 are non-ripe honey; B1, B2, and B3 are re-ripe honey). 
the fragrant odor in food (Renault et al., 2015). The non-ripe rape honey has acidic flagrant odor, which causes its low acceptance by the market. The high amounts of volatile alcohols generated in non-ripe honey were due to fermentation induced by the high water content (Pereira et al., 2015). The types and contents of VOCs in re-ripe honey were lower than those in non-ripe honey; as such, the former exhibited mild, fragrant, and non-irritating odor, which is easily accepted by consumers.

\section{Conclusion}

We used A. c. cerana colonies to produce re-ripe honey from non-ripe honey harvested from A. m. ligustica colonies during the rape flowering season. The water content, sugar composition, and amylase activity of re-ripe honey all meet the international criteria of honey. The production of re-ripe honey with colonies can significantly improve the market acceptance of re-ripe honey and beekeepers' economic profit considering the production rate. This study was conducted under strict control of external environmental conditions; as such, the results can provide a theoretical basis for popularization and standardization of production of re-ripe honey with colonies. However, further studies should be conducted to estimate and improve re-ripe honey production by optimizing colony management, selecting appropriate production season, and avoiding bee disease transmission and pesticides residues.

\section{References}

Abusabbah, M., Lau, W. H., Mahmoud, M. E. E., Salih, A. M., \& Omar, D. (2016). Prospects of using carbohydrates as supplemented-diets and protein rich mixture as alternative-diet to improve the quality of venom produced by Apis cerana L. Journal of Entomology and Zoology Studies, 4(3), 23-26.

Aparna, A. R., \& Rajalakshmi, D. (1999). Honey-its characteristics, sensory aspects, and applications. Food Reviews International, 15(4), 455-471. http://dx.doi.org/10.1080/87559129909541199.

Aldridge, R. L., Britch, S. C., Allan, S. A., Tsikolia, M., Calix, L. C., Bernier, U. R., \& Linthicum, K. J. (2016). Comparison of volatiles and mosquito capture efficacy for three carbohydrate sources In a yeast-fermentation $\mathrm{CO}_{2}$ generator. Journal of the American Mosquito Control Association, 32(4), 282-291. http://dx.doi.org/10.2987/166609.1. PMid:28206863.

Alvarez-Suarez, J. M., Gasparrini, M., Forbes-Hernández, T. Y., Mazzoni, L., \& Giampieri, F. (2014). The composition and biological activity of honey: a focus on Manuka honey. Foods, 3(3), 420-432. http:// dx.doi.org/10.3390/foods3030420. PMid:28234328.

Al, M. L., Daniel, D., Moise, A., Bobis, O., Laslo, L., \& Bogdanov, S. (2009). Physico-chemical and bioactive properties of different floral origin honeys from Romania. Food Chemistry, 112(4), 863-867. http://dx.doi.org/10.1016/j.foodchem.2008.06.055.

Ajlouni, S., \& Sujirapinyokul, P. (2010). Hydroxymethylfurfuraldehyde and amylase contents in Australian honey. Food Chemistry, 119(3), 1000-1005. http://dx.doi.org/10.1016/j.foodchem.2009.07.057.

Baltrušaitytè, V., Venskutonis, P. R., \& Čeksteryte, V. (2007). Radical scavenging activity of different floral origin honey and beebread phenolic extracts. Food Chemistry, 101(2), 502-514. http://dx.doi. org/10.1016/j.foodchem.2006.02.007.

Baroni, M. V., Nores, M. L., Díaz, M. D. P., Chiabrando, G. A., Fassano, J. P., Costa, C., \& Wunderlin, D. A. (2006). Determination of volatile organic compound patterns characteristic of five unifloral honey by solid-phase microextraction - gas chromatography - mass spectrometry coupled to chemometrics. Journal of Agricultural and Food Chemistry, 54(19), 7235-7241. http://dx.doi.org/10.1021/ jf061080e. PMid:16968088.

Bogdanov, S., Jurendic, T., Sieber, R., \& Gallmann, P. (2008). Honey for nutrition and health: a review. Journal of the American College of Nutrition, 27(6), 677-689. http://dx.doi.org/10.1080/07315724.2 008.10719745. PMid:19155427.

Cao, L. F., Zheng, H. Q., Pirk, C. W. W., Hu, F. L., \& Xu, Z. W. (2016). High royal jelly-producing honeybees (Apis mellifera ligustica) (Hymenoptera: Apidae) in China. Journal of Economic Entomology, 109(2), 510-514. http://dx.doi.org/10.1093/jee/tow013. PMid:26921226.

Castro-Vázquez, L., Leon-Ruiz, V., Alañon, M. E., Pérez-Coello, M. S., \& González-Porto, A. V. (2014). Floral origin markers for authenticating Lavandin honey (Lavandula angustifolia $x$ latifolia). Discrimination from Lavender honey (Lavandula latifolia). Food Control, 37, 362370. http://dx.doi.org/10.1016/j.foodcont.2013.09.003.

Chataway, H. D. (1932). The determination of moisture in honey. Canadian Journal of Research, 6(5), 532-547. http://dx.doi.org/10.1139/ cjr32-041.

Ferreira, E. L., Lencioni, C., Benassi, M. T., Barth, M. O., \& Bastos, D. H. M. (2009). Descriptive sensory analysis and acceptance of stingless bee honey. Food Science \& Technology International, 15(3), 251-258. http://dx.doi.org/10.1177/1082013209341136.

Gao, Y., \& Zhao, Z. (2016). Chinese honey positioning and price trend in domestic market. Agricultural Science and Technology, 17(6), 1446-1450.

Ismaiel, S., Al Kahtani, S., Adgaba, N., Al-Ghamdi, A. A., \& Zulail, A. (2014). Factors that affect consumption patterns and market demands for honey in the Kingdom of Saudi Arabia. Food and Nutrition Sciences, 5(17), 1725-1737. http://dx.doi.org/10.4236/ fns.2014.517186.

Iurlina, M. O., \& Fritz, R. (2005). Characterization of microorganisms in Argentinean honeys from different sources. International Journal of Food Microbiology, 105(3), 297-304. http://dx.doi.org/10.1016/j. ijfoodmicro.2005.03.017. PMid:16169624.

Karousou, R., Koureas, D. N., \& Kokkini, S. (2005). Essential oil composition is related to the natural habitats: Coridothymus capitatus and Satureja thymbra in NATURA 2000 sites of Crete. Phytochemistry, 66(22), 2668-2673. http://dx.doi.org/10.1016/j. phytochem.2005.09.020. PMid:16289149.

Kaškonienè, V., \& Venskutonis, P. R. (2010). Floral markers in honey of various botanical and geographic origins: a review. Comprehensive Reviews in Food Science and Food Safety, 9(6), 620-634. http://dx.doi. org/10.1111/j.1541-4337.2010.00130.x.

Kumar, K. P. S., Debjit, B., \& Chandira, M. R. (2010). Medicinal uses and health benefits of honey: an overview. Journal of Chemical and Pharmaceutical Research, 2(1), 385-395.

Manyi-Loh, C. E., Ndip, R. N., \& Clarke, A. M. (2011). Volatile compounds in honey: a review on their involvement in aroma, botanical origin determination and potential biomedical activities. International Journal of Molecular Sciences, 12(12), 9514-9532. http://dx.doi. org/10.3390/ijms12129514. PMid:22272147.

Naef, R., Jaquier, A., Velluz, A., \& Bachofen, B. (2004). From the linden flower to linden honey-volatile constituents of linden nectar, the extract of bee-stomach and ripe honey. Chemistry \& Biodiversity, 1(12), 1870-1879. http://dx.doi.org/10.1002/cbdv.200490143. PMid:17191825. 
Ouchemoukh, S., Schweitzer, P., Bey, M. B., Djoudad-Kadji, H., \& Louaileche, H. (2010). HPLC sugar profiles of Algerian honeys. Food Chemistry, 121(2), 561-568. http://dx.doi.org/10.1016/j. foodchem.2009.12.047.

Ou, J., \& Sun, Z. (2014). Feruloylated oligosaccharides: structure, metabolism and function. Journal of Functional Foods, 7, 90-100. http://dx.doi.org/10.1016/j.jff.2013.09.028.

Pereira, A. P., Mendes-Ferreira, A., Estevinho, L. M., \& Mendes-Faia, A. (2015). Improvement of mead fermentation by honey-must supplementation. Journal of the Institute of Brewing, 121(3), 405410. http://dx.doi.org/10.1002/jib.239.

Renault, P., Coulon, J., de Revel, G., Barbe, J. C., \& Bely, M. (2015). Increase of fruity aroma during mixed $\mathrm{T}$. delbrueckii/S. cerevisiae wine fermentation is linked to specific esters enhancement. International Journal of Food Microbiology, 207, 40-48. http://dx.doi.org/10.1016/j. ijfoodmicro.2015.04.037. PMid:26001522.
Semkiw, P., Skowronek, W., Skubida, P., Rybak-Chmielewska, H., \& Szczesna, T. (2010). Changes occurring in honey during ripening under controlled conditions based on $\alpha$-amylase activity, acidity and 5-hydroxymethylfurfural content. Journal of Apicultural Science, 54(1), 55-64.

Turkmen, N., Sari, F., Poyrazoglu, E. S., \& Velioglu, Y. S. (2006). Effects of prolonged heating on antioxidant activity and colour of honey. Food Chemistry, 95(4), 653-657. http://dx.doi.org/10.1016/j. foodchem.2005.02.004.

Thrasyvoulou, A., Tananaki, C., Goras, G., Karazafiris, E., Dimou, M., Liolios, V., Kanelis, D., \& Gounari, S. (2018). Legislation of honey criteria and standards. Journal of Apicultural Research, 57(1), 88-96. http://dx.doi.org/10.1080/00218839.2017.1411181.

Xu, R., Cheng, N., Huang, W., Gao, H., Deng, J. D., \& Cao, W. (2012). Effects of the processing steps on parathion levels during honey production and parathion removal by macroporous adsorption resins. Food Control, 23(1), 234-237. http://dx.doi.org/10.1016/j. foodcont.2011.07.020. 